\title{
A Report on the National Bureau of Standards pH Standards
}

\author{
Y. C. Wu, W. F. Koch, and G. Marinenko \\ National Bureau of Standards, Gaithersburg, MD 20899
}

Accepted: September 19, 1984

\begin{abstract}
In 1980, the research program in $\mathrm{pH}$ was re-established at the National Bureau of Standards (NBS). This report describes the state of this research, as well as the state of the NBS pH standards. The thermodynamic definition and the determination of $\mathrm{pH}$ are elaborated. The problems of liquid junction potentials encountered in the practical determination of $\mathrm{pH}$ are discussed. The goal of the research program in $\mathrm{pH}$ is to develop and maintain a unified $\mathrm{pH}$ scale based on clearly stated thermodynamic criteria, with a wide range of applicability to practical $\mathrm{pH}$ measurements.
\end{abstract}

Key words: activity; activity coefficient; buffers; galvanic cell; glass electrode; hydrogen ion; liquid junction; pH; silver/silver chloride electrode; Standard Reference Materials; standards; thermodynamics.

\section{Introduction}

The negative logarithm of the hydrogen ion activity is commonly known as $\mathrm{pH}[1]^{1}$. This term is associated with the effective concentration of hydrogen ion. The importance of this quantity lies in the fact that it is the measure of the chemical reactivity of the acid and alkali in aqueous solutions. It is used extensively in monitoring agricultural and industrial processes. Functionally, $\mathrm{pH}$ lies at the base of many chemical synthetic processes and is essential in many analytical measurements. In biological and biochemical research, $\mathrm{pH}$ is important because it is fundamental to natural processes. In short, $\mathrm{pH}$ is intrinsic to life itself.

The determination of $\mathrm{pH}$ is based on physicochemical principles and can be performed by various techniques such as colorimetry, conductivity, and potentiometry.

About the Authors: All the authors are research chemists in the Inorganic Analytical Research Division of NBS' Center for Analytical Chemistry.

\footnotetext{
${ }^{1}$ Numbers in brackets indicate literature references at the end of this paper. It should be noted here that the original definition was in terms of hydrogen ion concentration. It was S. P. L. Sorenson and K. Linderstrom-Lang (Compt. Rend. Trav. Carlsberg 15, 40, 1924) who first proposed hydrogen ion activity in the definition.
}

Of these, the potentiometric or the electromotive force (emf) method is the simplest, the most accurate, and hence the most widely used. This is particularly true since the invention and commercialization of the hydrogen ion sensitive glass electrode.

The employment of the glass electrode for determining $\mathrm{pH}$ generally requires the following arrangement:

$$
\text { Glass electrode|Test solution\| }
$$

Salt bridge solution $\mid$ Reference electrode

where the single vertical bar is the electrode-solution interface and the double vertical bar is a liquid junction denoting an interface between the test solution and the salt bridge solution, the latter having an ion in common with the reference electrode. From the measured electromotive force of cell (I) the $\mathrm{pH}$ may be computed via the following equation:

$$
\mathrm{pH} \equiv \log \mathrm{a}_{\mathrm{H}}=\frac{E-\left(E_{\mathrm{pH}}^{\circ}+E \mathrm{j}\right)}{R T \ln 10 / F}=\frac{E-E_{\mathrm{pH}}^{\circ}}{k}
$$

$$
\begin{aligned}
\text { where } \mathrm{a}_{\mathrm{H}}= & \text { the hydrogen ion activity (the charge, }+, \\
& \text { is dropped for convenience) } \\
E= & \text { the observed emf of the cell } \\
E_{\mathrm{pH}}^{\circ}= & \text { a constant, dependent on temperature and } \\
& \text { pressure and the types of electrodes used }
\end{aligned}
$$




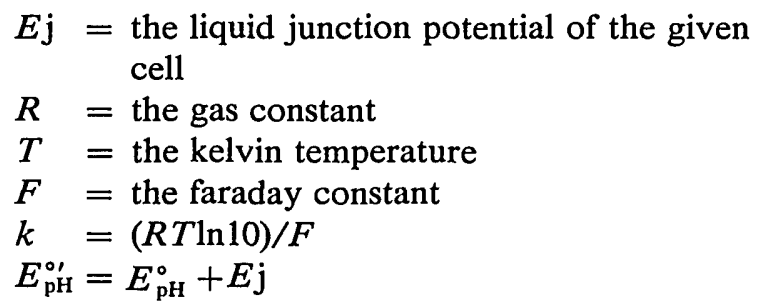

The last quantity, $E_{\mathrm{pH}}^{\circ}$, cannot be accurately evaluated. However if $E_{\mathrm{pH}}^{\circ}$ is assumed to be constant for a given system [2], and if a solution of known $\mathrm{pH}[\mathrm{pH}(\mathrm{S})]$ is available, then the $\mathrm{pH}$ of an unknown solution [pH(X)] can be determined by using cell (I) twice: first with solution $\mathrm{S}$, then with solution $\mathrm{X}$ and calculating the $\mathrm{pH}(\mathrm{X})$ from the difference in the respectively measured emf's as follows:

$$
\mathrm{pH}(\mathrm{X})=\mathrm{pH}(\mathrm{S})+\frac{E_{\mathrm{X}}-E_{\mathrm{S}}}{k} .
$$

If $\mathrm{pH}(\mathrm{X})$ differs significantly from $\mathrm{pH}(\mathrm{S})$ or if the emf response of the system differs from the ideal Nernstian response of $1 \mathrm{pH}$ unit per volt $(R T \ln 10 / F)$, then two $\mathrm{pH}$ standards (S1 and S2) should be used. The value of $\mathrm{pH}(\mathrm{X})$ can be computed according to eq (3):

$$
\mathrm{pH}(\mathrm{X})=\mathrm{pH}(\mathrm{S} 1)+\frac{E_{\mathrm{X}}-E_{\mathrm{S} 1}}{E_{\mathrm{S} 2}-E_{\mathrm{S} 1}}[\mathrm{pH}(\mathrm{S} 2)-\mathrm{pH}(\mathrm{S} 1) .
$$

The choice of the two buffers S1 and S2 should be such that $\mathrm{pH}(\mathrm{X})$ falls between the values $\mathrm{pH}(\mathrm{S} 1)$ and $\mathrm{pH}(\mathrm{S} 2)$. Such is the practical determination of $\mathrm{pH}$ today.

Therefore, the availability of standard $\mathrm{pH}$ solutions is a necessary condition for the application of eq (2). Moreover, according to the application of Henderson's or Planck's equation for the approximation of the liquid junction potential, $E \mathrm{j}$ [3-5], the standard $\mathrm{pH}$ solution should be made as similar to the test solution as possible with respect to $\mathrm{pH}$ and composition. Under such conditions the assumption regarding the constancy of $E_{\mathrm{pH}}^{\circ}$ is sound. Since in practice the conventional $\mathrm{pH}$ scale spans $14 \mathrm{pH}$ units, several $\mathrm{pH}$ standards are required for establishing calibration points over the entire $\mathrm{pH}$ range.

In the United States, $\mathrm{pH}$ standards are promulgated and maintained by the National Bureau of Standards (NBS). Many foreign countries have also adopted the NBS approach to $\mathrm{pH}$ standardization. This work has been performed at NBS since the late 1930s [6] through the issuance of Standard Reference Materials. This approach, as well as the materials and values for the NBS pH buffer standards, have been accepted internationally. The theory and practices which are at the base of the certification process undergo periodic critical examination at NBS to remain current with new developments and technology and to be responsive to changing and expanding national needs. A detailed discussion of the theory, the process, and the refinement of the evaluation and certification of $\mathrm{pH}$ standards at the NBS follows.

\section{Thermodynamic Foundation of pH}

The use of $\mathrm{pH}$ in the expression $\mathrm{pH}=-\log \mathrm{a}_{\mathrm{H}}$ is purely a formalism because $\mathrm{a}_{\mathrm{H}}$, a single (hydrogen) ion activity, is indeterminate. The ultimate definition of $\mathrm{pH}$ should be made in terms of determinable quantities.

One way of determining the $\mathrm{pH}$ of a weak acid (HA) may be from the dissociation constant, $K_{\mathrm{a}}$, of the acid, assuming $K_{\mathrm{a}}$ is known or can be independently determined:

$$
K_{\mathrm{a}}=\frac{\mathrm{a}_{\mathrm{H}} \mathrm{a}_{A}}{\mathrm{a}_{\mathrm{H} A}}=\frac{\mathrm{a}_{\mathrm{H}} m_{A} \gamma_{A}}{m_{\mathrm{H} A} \gamma_{\mathrm{H} A}}
$$

and

$$
\mathrm{pH}=\mathrm{p} K \mathrm{a}+\log \frac{m_{A}}{m_{\mathrm{H} A}}+\log \frac{\gamma_{A}}{\gamma_{\mathrm{H} A}} .
$$

With the aid of the Debye-Hückel equation [7, 8]

$$
\log \gamma_{\mathrm{i}}=-A Z_{\mathrm{i}}^{2} \sqrt{\mathrm{I}} /\left(1+B \mathrm{a}_{\mathrm{i}} \sqrt{I}\right)+b I
$$

where $m=$ molality of the constituents

$\gamma_{\mathrm{i}}=$ activity coefficient of the ith species

$I=\frac{1}{2} \Sigma m_{\mathrm{i}} Z_{\mathrm{i}}^{2}$. (This is the definition of ionic strength only if the electrolyte is fully dissociated. Otherwise, the degree of dissociation, $\alpha$, should be included. Thus $I=\frac{1}{2} \Sigma \alpha m_{\mathrm{i}} Z_{\mathrm{i}}^{2}$, e.g., $I$ for $0.05 \mathrm{~m}$ potassium acid phthalate (KHP) at $25^{\circ} \mathrm{C}$ is not 0.05 but 0.0533 [9].)

$Z_{\mathrm{i}}=$ ionic charge of the ith ion

$A$ and $B=$ constants dependent on the temperature and dielectric constant of the solvent

$\stackrel{a}{\mathrm{i}}_{\mathrm{i}} \quad=$ the ionic size

$b=$ an adjustable parameter

On the other hand, the $\mathrm{pH}$ of the same acid can be determined without the knowledge of $K_{\mathrm{a}}$, using a galvanic cell without liquid junction, sometimes called the Harned cell:

$$
\mathrm{Pt}, \mathrm{H}_{2}(1 \text { atm. })\left|\mathrm{H} A(m), \mathrm{KCl}\left(m^{\prime}\right)\right| \mathrm{AgCl}, \mathrm{Ag} \text {. }
$$

The emf of this cell at one atmosphere $(101.325 \mathrm{kPa})$ of hydrogen pressure is given by

$$
E=E_{\mathrm{Ag}, \mathrm{AgCl}}^{\circ}-\frac{R T}{F} \ln m_{\mathrm{H}} m_{\mathrm{Cl}} \gamma_{\mathrm{H}} \gamma_{\mathrm{Cl}}
$$


where $m$ 's are molalities, $\gamma$ 's the activity coefficients, $R, T, F$ have their usual significance, and $E$ is the measured emf. $E_{\mathrm{Ag}, \mathrm{AgCl}}^{\circ}$ is the potential of the silver-silver chloride electrode measured relative to the "standard hydrogen electrode," i.e.,

$$
\frac{1}{2} \mathbf{H}_{2}(\mathrm{~g})=\mathrm{H}^{+}+\mathrm{e}
$$

and

$$
E=E_{\mathrm{H}}^{\circ}-\frac{R T}{F} \ln \frac{\mathrm{a}_{\mathrm{H}}{ }^{+}}{\mathrm{p}_{\mathrm{H} 2}{ }^{1 / 2}}
$$

where $p$ is the pressure of the $\mathrm{H}_{2}$ gas. When $p=p^{\circ} \equiv 1$, atmosphere and $\mathrm{a}_{\mathrm{H}}{ }^{+}=\mathrm{a}_{\mathrm{H}}^{\circ} \equiv 1$, then, $E=E_{\mathrm{H}}^{\circ}$. Since halfcell potentials cannot be measured independently, it has been established by convention that $E_{\mathrm{H}}^{\circ}=0$ at $\mathrm{p}_{\mathrm{H}}^{\circ}$ and at all temperatures. All other half-cell potentials are computed in relation to $E_{\mathrm{H}}^{\circ}=0$.

By putting all the known quantities together on the right hand side, eq (7) may be rewritten as

$$
-\log \mathrm{a}_{\mathrm{H}} \gamma_{\mathrm{Cl}}=\frac{E-E^{\circ}}{k}+\log m_{\mathrm{Cl}}
$$

Since by definition $\gamma_{\mathrm{Cl}}=1$ as $m$ goes to zero, by plotting the right hand side of eq (10) vs $m_{\mathrm{Cl}}$ and extrapolating to $m_{\mathrm{Cl}}=0$, the limiting value of the acidity function can be expressed as $-\log \left(\mathrm{a}_{\mathrm{H}} \gamma_{\mathrm{Cl}}\right)_{I}^{\circ}$ [9]. This value corresponds to the acidity function at the particular ionic strength, $I$, of the weak acid HA and

$$
\mathrm{pH}=-\log \left(\mathrm{a}_{\mathrm{H}} \gamma_{\mathrm{Cl}}\right)_{I}^{\circ}+\log \gamma_{(\mathrm{at} n} .
$$

The last term of eq (11) may be evaluated from eq (6). Therefore, all the quantities related to $\mathrm{pH}$, either from the dissociation constant or from the emf of galvanic cells without liquid junction, can be determined. Hence, within this framework the term $\mathrm{pH}$ is defined.

It should be noted that the application of eq (6) for the evaluation of the activity coefficients requires assumptions outside the domain of thermodynamics. However, it has been experimentally proved that this equation is a suitable approximation for the activity coefficient function of strong electrolytes up to 1 molal concentration $[10,11]$ and therefore the use of this equation is justified for the determination of $\mathrm{pH}$ at ionic strength lower than 1 molal.

As the ionic strength decreases, the $b$-term in eq (6) becomes insignificant, and the influence of $a_{i}$ also decreases. By selecting a value for $B \mathrm{a}_{\mathrm{i}}$ (for example 1.5 , as recommended by the Bates-Guggenheim convention $[12,13]$ at the ionic strength of around 0.1 molal), the resultant uncertainty in $\mathrm{pH}$ is less than $0.005 \mathrm{pH}$ unit, even if $B \dot{a}_{\mathrm{i}}$ is varied by as much as $10 \%$. The ionic strength of the standard $\mathrm{pH}$ solutions certified by NBS is $\leqslant 0.1$. Thus the Bates-Guggenheim convention,

$$
\log \gamma_{\mathrm{i}}=-\frac{\mathrm{Az}_{\mathrm{i}} \sqrt{I}}{1+1.5 \sqrt{I}}
$$

is justified within the present experimental uncertainty (see table 1), and is applicable to the certification of the NBS primary buffer standards.

New demands for $\mathrm{pH}$ standards of ionic strength greater than 0.1 molal, such as that for seawater, render the use of Bates-Guggenheim convention inapplicable. In these cases eq (6) must be used, and the values of $a_{\mathrm{i}}$ and $b$ must be determined experimentally.

\section{NBS Standardization of pH Solutions}

The standardization of $\mathrm{pH}$ solutions was initiated at NBS in the late 1930's when Hamer [14] suggested the use of a galvanic cell without a liquid junction, similar to cell II, for the purpose. Later Hamer and Acree [6] proved experimentally the applicability of cell II for the determination of pH. Early in the 1940's, Bates et al. [15] published a list of provisional $\mathrm{pH}$ values of standard buffers. In the following years the experimental setup and the treatment of data were significantly refined as the state of the art of measurement advanced.

The principle of the determination of $\mathrm{pH}$ and the thermodynamics of the establishment of a $\mathrm{pH}$ scale have been discussed in section 2. Because of the complexity of ionic interactions in electrolyte solutions, the knowledge of ionic activity or activity coefficients has been advanced little in recent years. The only improvements that have occurred in the determination of $\mathrm{pH}$ have been in the methods of measurement. Among various methods for determining $\mathrm{pH}$, Hamer et al. $[6,14]$ and later Bates $[12,16]$ have ably demonstrated that a galvanic cell without a liquid junction,

$$
\text { Pt, } \mathrm{H}_{2}(1 \mathrm{~atm}) \mid \mathrm{H}^{+} \text {solution, } \mathrm{KCl}(m) \mid \mathrm{AgCl}, \mathrm{Ag}
$$

is the best suited for the purpose. A detailed experimental account has been given by Durst [17].

Since eq (7) is used for the determination of $\mathrm{pH}$, it is necessary to know $E_{\mathrm{Ag}, \mathrm{AgCl}}^{\circ}$. The value of $E_{\mathrm{Ag}, \mathrm{AgCl}}^{\circ}$ is determined, using the following cell [10]:

$$
\mathrm{Pt}, \mathrm{H}_{2}(1 \mathrm{~atm})|\mathrm{HCl}(m)| \mathrm{AgCl}, \mathrm{Ag}
$$

and the equation 


$$
E_{\mathrm{Ag}, \mathrm{AgCl}}^{\circ}=E_{\text {cell }}-E_{\mathrm{H}}^{\circ}
$$

where $E_{\mathrm{H}}^{\circ} \equiv 0$, under the conditions described in the previous section. However, the best values of $E^{\circ}$ reported for this cell disagree by $0.2 \mathrm{mV}$ or more $[18,19]$. This indicates that not all silver-silver chloride electrodes behave identically. Therefore, for the most accurate $\mathrm{pH}$ work, the $E^{\circ}$ value of each individual $\mathrm{Ag}, \mathrm{AgCl}$ electrode must be determined in cell III and the stability of each electrode firmly established before it may be used in cell II.

Using cell II, relying on thermodynamic principles, and by adopting the Bates-Guggenheim convention, the NBS has certified seven primary and three secondary $\mathrm{pH}$ standards. They are listed in table 1 . The uncertainty associated with each of the primary standards is 0.005 $\mathrm{pH}$ and the uncertainty of the secondary standards is $0.01 \mathrm{pH}$.

The widespread use of cell I for practical $\mathrm{pH}$ measurements necessitates the use of $\mathrm{pH}$ standards that are traceable to the primary standards for calibration purposes. The work at NBS satisfies this need by providing definitively calibrated and certified $\mathrm{pH}$ standards.

The advantages and shortcomings of cell I have been discussed in section 1. Nevertheless, it is of interest to examine the data obtained with cell I by using a combination glass electrode to test the internal consistency of the NBS pH standards. The results are shown in table 2. The maximum deviation among all $\mathrm{pH}(\mathrm{S})$ listed in table 2 is $0.002 \mathrm{pH}$ units. The NBS $\mathrm{pH}$ scale is internally consistent to at least that extent, thus confirming the usefulness of the approximations and conventions described in the first part of this report.

\section{The Operational Determination of $\mathrm{pH}$ and the Problem of Liquid Junction.}

The operational definition of $\mathrm{pH}$ entails the measurement of $\mathrm{pH}$ with cell I and the comparison of the $\mathrm{pH}$ of the unknown solution with that of the standard as shown in eq (2). Such comparison assumes the constancy of the liquid junction potential, $E \mathbf{j}$, in eq (1). This assumption has only limited validity. In some instances significant errors may be introduced in the $\mathrm{pH}$ determination by this assumption.

The problem of liquid junction potential has been the

Table 2. Internal consistency of the NBS pH scale.

\begin{tabular}{ccc}
\hline \hline Standard Solution & $25^{\circ} \mathrm{C}$ & $\Delta \mathrm{pH}$ \\
\hline $1: 1$ Phosphate & & \\
pH(S) & 6.863 & +0.002 \\
pH(meas) & 6.861 & \\
Tartrate & & \\
pH(S) & 3.639 & +0.001 \\
pH(meas) & 3.638 & \\
Phthalate & & \\
pH(S) & 4.004 & -0.002 \\
pH(meas) & 4.006 & \\
Borax & & \\
pH(S) & 9.183 & -0.001 \\
pH(meas) & 9.184 & \\
Carbonate & & +0.000 \\
pH(S) & 10.014 & \\
pH(meas) & 10.014 & \\
\hline
\end{tabular}

Table 1. NBS pH Standards.

\begin{tabular}{|c|c|c|c|}
\hline $\begin{array}{l}\text { Solution composition } \\
\text { (molality) }\end{array}$ & $\begin{array}{r}\mathrm{pH}(\mathrm{S}) \\
\text { at } 25^{\circ} \mathrm{C}\end{array}$ & $\begin{array}{c}\text { Temperature } \\
\text { range }\left({ }^{\circ} \mathrm{C}\right)\end{array}$ & SRM \\
\hline \multicolumn{4}{|l|}{ Primary Standards:* } \\
\hline potassium hydrogen tartrate (satd. at $25^{\circ} \mathrm{C}$ ) & 3.557 & 25 to 95 & 188 \\
\hline $0.05 \mathrm{~m}$ potassium dihydrogen citrate & 3.776 & 0 to 50 & \\
\hline $0.05 \mathrm{~m}$ potassium acid phthalate & 4.006 & 0 to 50 & $185 f$ \\
\hline $0.025 m \mathrm{KH}_{2} \mathrm{PO}_{4}+0.025 m \mathrm{Na}_{2} \mathrm{HPO}_{4}$ & 6.863 & 0 to 50 & $186 \mathrm{Id} / 186 \mathrm{IId}$ \\
\hline $0.008695 m \mathrm{KH}_{2} \mathrm{PO}_{4}+0.03043 m \mathrm{Na}_{2} \mathrm{HPO}_{4}$ & 7.410 & 0 to 50 & $186 \mathrm{Id} / 186 \mathrm{IId}$ \\
\hline $0.01 m \mathrm{Na}_{2} \mathrm{~B}_{4} \mathrm{O}_{7} \cdot 10 \mathrm{H}_{2} \mathrm{O}$ & 9.180 & 0 to 50 & $187 \mathrm{c}$ \\
\hline $0.025 m \mathrm{NaHCO}_{3}+0.025 \mathrm{~m} \mathrm{Na}_{2} \mathrm{CO}_{3}$ & 10.010 & 0 to 50 & $191 \mathrm{a} / 192 \mathrm{a}$ \\
\hline \multicolumn{4}{|l|}{ Secondary Standards:** } \\
\hline $0.05 \mathrm{~m}$ potassium tetroxalate $\cdot 2 \mathrm{H}_{2} \mathrm{O}$ & 1.679 & 0 to 95 & 189 \\
\hline $0.01667 m$ tris $^{* * *}+0.05 m$ tris $\cdot \mathrm{HCl}$ & 7.699 & 0 to 50 & $922 / 923$ \\
\hline $\mathrm{Ca}(\mathrm{OH})_{2}$ (satd. at $25^{\circ} \mathrm{C}$ ) & 12.454 & 0 to 60 & \\
\hline
\end{tabular}

Experimental uncertainty: $\pm 0.005 \mathrm{pH}$

**Experimental uncertainty: $\pm 0.01 \mathrm{pH}$

***tris: tris(hydroxymethyl)aminomethane. 
subject of numerous studies $[2,14,20,21]$ which indicate that the liquid junction potential is not a thermodynamic quantity, i.e., that the liquid junction potential, $E \mathrm{j}$, cannot be specifically defined. For example, $E \mathrm{j}$ depends on the concentration of the salt bridge and on the temperature, but no functional correlation has been found. $E \mathrm{j}$ also varies with specific electrolytes, such as strong and weak acids. Furthermore, it changes with the geometrical structure and the manner in which the junction of the salt bridge is formed [14,20]. Therefore, $E \mathrm{j}$ cannot be determined exactly and eq (2) cannot be considered a rigorous thermodynamic definition of $\mathrm{pH}$.

For the reasons outlined above, one cannot in general assume $E \mathrm{j}$ to be constant in determining $\mathrm{pH}$ in solutions of unknown nature. It has been reported that the uncertainty in determining $\mathrm{pH}$ in acid ra $\left.{ }^{a_{4}}{ }_{[2}^{[2}\right]$ and in biological fluids [23], using a combination glass electrode in cell $\mathrm{I}$, is significant, often as large as $0.5 \mathrm{pH}$.

\section{Research on $\mathrm{pH}$}

An active research program in $\mathrm{pH}$ has been established at NBS to maintain the standards used for $\mathrm{pH}$ calibration, to respond to changing needs in this important determination, and to advance the science in tune with advances in chemical and electronic technology. This research effort includes both basic and applied studies and its diversity is illustrated by two projects now in progress.

Basic research is being conducted to establish firmly the standard potential $\left(E^{\circ}\right)$ of the $\mathrm{Ag}, \mathrm{AgCl}$ electrochemical couple which is often used as the reference electrode in $\mathrm{pH}$ measurements. As alluded to in a previous section, there are variations in the measured $E^{\circ}$ of different preparations of $\mathrm{Ag}, \mathrm{AgCl}$ electrodes. Recently, Bates [18] has reported that from over 30 independent measurements, values for $E^{\circ}$ of $\mathrm{Ag}, \mathrm{AgCl}$ determined in cells without liquid junction vary from 0.2222 to $0.2228 \mathrm{~V}$ at $25^{\circ} \mathrm{C}$. The range is $0.0006 \mathrm{~V}$, which amounts to differences of approximately $0.01 \mathrm{pH}$ unit.

Variations in $E^{\circ}$ of such magnitude $(0.6 \mathrm{mV})$ must be caused by the $\mathrm{Ag}, \mathrm{AgCl}$ electrode itself, because the other factors in the system for determining $E^{\circ}$ can be systematically eliminated. In fact, experts decided in 1956 to assign an uncertainty of $0.2 \mathrm{mV}$ to the $E^{\circ}$ measurements for this electrode [24]. The sources of problems associated with this electrode have been investigated by numerous workers in electrochemistry. The areas studied have included methodology, electrode preparation, and operational precautions. However, there is still need to define the characteristics of this electrode to reduce the uncertainties associated with $\mathrm{pH}$ measurements done on SRM's at NBS.
When classical experiments [19, wherein references cited] were repeated, it was observed that oxygen interacted with the electrode and was probably the major cause of the observed variations in $E^{\circ}$. Although this observation was not new, the effect has never been fully discussed and investigated. To verify the effect of oxygen on the behavior of the electrode, we conducted the following experiments:

A. Electrode Preparation: A thermal electrolytic type of preparation was selected because the method is sim ple and results in an electrode with minimal (or least) contamination. Classical procedures were followed, except when electrodes were purposely exposed to either laboratory air or an argon atmosphere.

B. Cell EMF Measurement: The cell setup, temperature control, and measuring device were similar to those described by Durst [17] with minor modifications. Special care was taken to have the electrode and $\mathrm{HCl}$ solution under either laboratory air or an argon atmosphere. Measurements were made immediately after the preparation of the electrodes.

Four sets of experimental conditions were compared:
(a) $E_{\mathrm{el}(\mathrm{O})}-\mathrm{S}(\mathrm{O})$
(b) $E_{\mathrm{el}(0)}-\mathrm{S}(\mathrm{Ar})$
(c) $E_{\mathrm{el}(\mathrm{Ar})}-\mathrm{S}(\mathrm{O})$
(d) $E_{\mathrm{el}(\mathrm{Ar})}-\mathrm{S}(\mathrm{Ar})$

where el $(\mathrm{O})=$ electrode exposed to air, el(Ar) =electrode exposed to argon, $\mathrm{S}(\mathrm{O})=\mathrm{HCl}$ solution saturated with air, $\mathrm{S}(\mathrm{Ar})=\mathrm{HCl}$ solution saturated with argon. The ranges of results for approximately 100 electrode measurements under the four sets of experimental conditons respectively are:

(a) $E^{\circ}=0.22260$ to $0.22350 \mathrm{~V}$

(b) $E^{\circ}=0.22250$ to $0.22260 \mathrm{~V}$

(c) $E^{\circ}=0.22240$ to $0.22250 \mathrm{~V}$

(d) $E^{\circ}=0.22230$ to $0.22240 \mathrm{~V}$.

The results indicate that oxygen does have an effect on the $E^{\circ}$ for the $\mathrm{Ag}, \mathrm{AgCl}$ electrode, and is most pronounced in those measurements made with electrodes exposed to an oxygen atmosphere. The higher potentials observed for such electrodes are probably due to mixed potentials from electrochemical couples other than silver-silver chloride, silver-silver oxide, for instance. However, the long term stability could not be maintained and the overall reproducibility for each set was only $\pm 0.05 \mathrm{mV}$ as compared with 0.01 to $0.02 \mathrm{mV}$ as reported in the literature $[10,19,25]^{2}$. Work is continuing

\footnotetext{
${ }^{2}$ It was pointed out by Hamer [26] that Harned and his students used "limited" solutions and filled their cells under vacuum to get rid of the "air effect." Harned and Ehlers [27] thus obtained $E^{\circ}=0.22239$ int. volts. On the present scale this becomes $0.22247 \mathrm{~V}$ which is in good agreement with conditions (c).
} 
in the areas of oxygen adsorption and desorption measurements to determine quantitatively the effects of oxygen on $E^{\circ}$. This work is necessary to lower the uncertainties in existing $\mathrm{pH}$ measurements.

In the second project, work is proceeding to develop matrix-specific $\mathrm{pH}$ standards to augment the primary buffer standards currently available. The major reason for these new standards is to take into account residual liquid junction potentials and to minimize their effect. It has been shown conclusively that these effects can seriously bias $\mathrm{pH}$ readings, especially if the ionic strengths of the standards and the test solutions are significantly different [22].

Research is now underway to test the feasibility of providing matrix-specific $\mathrm{pH}$ standards for selected applications, focusing initially on low ionic strength solutions such as acidic precipitation in the environment.

Recently an interlaboratory test was conducted to test the efficiency of using dilute solutions of a strong acid as working standards for $\mathrm{pH}$ measurements in acidic precipitation. The results of this test confirm the problems with residual liquid junction potentials and indicate that the strong acid standards (specific for this application) greatly minimize the problem. It is anticipated that in late 1984 NBS will issue a Research Material (RM) which will incorporate these findings and represent the first attempt at matrix-specific $\mathrm{pH}$ standards. The effort will be expanded to include matrices such as seawater, biological fluids, and eventually, non-aqueous media. This new generation of $\mathrm{pH}$ standards will be consistent with the current NBS $\mathrm{pH}$ scale and will be as thermodynamically meaningful as possible. This should avoid the confusion that would be caused by several inconsistent $\mathrm{pH}$ scales.

The ultimate goal of the NBS research program on $\mathrm{pH}$ is to develop and maintain a unified $\mathrm{pH}$ scale based on clearly stated thermodynamic criteria, with a wide range of applicability to practical $\mathrm{pH}$ measurements. The present projects form the foundation for this goal and will lead to intensive investigations into activity coefficients and the concept of single ion activities.

\section{References}

[1] Sorensen, S. P. L., Comp. Rend. Lab. Carlsberg 8, 1 (1909).

[2] Hitchcock, D. I., and A. C. Taylor, J. Am. Chem. Soc. 59, 1912 (1937).

[3] Guggenheim, E. A., J. Am. Chem. Soc. 52, 1315 (1930).

[4] Henderson, P., Z. Physik. Chem. 59, 118 (1907).

[5] Plank, M., Wied. Ann. 39, 161 (1890); 40, 561 (1890).

[6] Hamer, W. J., and S. F. Acree, J. Res. Natl. Bur. Stand. 23, 647 (1939).

[7] Debye, P., and E. Hückel, Physik. Z. 24, 185 (1923).

[8] Hückel, E., Physik. Z. 26, 93 (1925).

[9] Hamer, W. J., and S. F. Acree, J. Res. Natl. Bur. Stand. 32, 215 (1944).

[10] Harned, H. S., and B. B. Owen, The Physical Chemistry of Electrolytic Solutions, 3d ed., Reinhold Book Corp., New York, 1958.

[11] Robinson, R. A., and R. H. Stokes, Electrolyte Solutions, 2d ed., Butterworths Scientific Publ., London, 1959.

[12] Bates R. G., Determination of pH, John Wiley \& Sons, New York, 1973.

[13] Bates, R. G., and E. A. Guggenheim, Pure Appl. Chem. 1, 163 (1960).

[14] Hamer, W. J., Trans. Electrochem. Soc. 7, 45 (1937).

[15] Bates, R. G., W. J. Hamer, G. G. Manov, and S. F. Acree, J. Res. Natl. Bur. Stand. 29, 183 (1942).

[16] Bates, R. G., CRC Crit. Rev. Anal. Chem. 247 (1981).

[17] Durst, R. A., Standardization of $p H$ Measurements, Natl. Bur. Stand. SP260-53, Natl. Bur. Stand., 1975.

[18] Bates, R. G., Pure Appl. Chem. 50, 1701 (1978).

[19] Ives, D. J. G. and G. Janz, eds. Reference Electrodes, Academic Press, New York, 1961

[20] Clark, W. M., The Determination of Hydrogen Ions, 3d ed. Williams and Wilkins Co., Baltimore, 1928.

[21] MacInnes, D. A., The Principles of Electrochemistry, Reinhold Publ. Corp., New York (1939).

[23] Koch, W. F., and G. Marinenko, ASTM Special Technical Publication 823, 10-17 (1981).

[23] Illingworth, J. A., Biochem. J. 195, 259-262 (1981).

[24] Bates, R. G.; E. A. Guggenheim, H. S. Harned, D. J. G. Ives, G. J. Janz, C. B. Monk, R. A. Robinson, R. H. Stokes, and W. F. K. Wynne-Jones, J. Chem. Physics. 25, 361 (1956).

[25] Bates, R. G., and V. E. Bower, J. Res. Natl. Bur. Stand. 53, 283 (1954).

[26] Hamer, W. J., private communications.

[27] Harned, H. S., and R. W. Ehlers, J. Am. Chem. Soc. 54, 1350 (1932). 